\title{
Who should pay for tropical conservation, and how could the costs be met?
}

\author{
Andrew Balmford and Tony Whitten
}

\begin{abstract}
While conservation activities are underfunded almost everywhere, the gap between current expenditure and what is needed is particularly extreme in the tropics where threatened species and habitats are most concentrated. We examine how to bridge this funding gap. Firstly, we try to identify who in principle should pay, by comparing the spatial distribution of the costs and the benefits of tropical conservation. The immediate opportunity costs of conservation often exceed its more obvious, management-related costs, and are borne largely by local communities. Conversely, we argue that the greatest benefits of conservation derive from ecological services, and from option, existence, and bequest values; these are often widely dispersed and enjoyed in large part by wealthier national and global beneficiaries. We conclude that the gap in funding tropical conservation should be borne largely by national and especially global communities, who receive most benefit but currently pay
\end{abstract}

least cost. In the second part of the paper we review recent developments in order to examine how in practice increased funding may be raised. There are many growing and novel sources of support: private philanthropy, premium pricing for biodiversity-related goods via certification schemes, and the development of entirely new markets for environmental services. Despite their potential, we conclude that the principal route for meeting the unmet costs of tropical conservation will have to be via governments, and will inevitably require the transfer of substantial resources from north to south. This will be enormously difficult, both politically and logistically, but without it we believe that much of what remains of tropical nature will be lost.

Keywords Ecological services, conservation costs, funding gap, opportunity costs, option values, tropical conservation.

\section{The problem}

Attempts to conserve tropical nature are reaching crisis point. On the one hand, more species and more habitats are at risk in the tropics than elsewhere, due to a combination of rapidly rising human populations, increasing per capita consumption, and the higher densities in tropical areas of both species in general and intrinsically vulnerable species with small range sizes in particular (BirdLife International, 2000; IUCN, 2002; Fig. 1a). On the other hand, while in overall terms conserving what remains of wild nature makes striking economic sense (Balmford et al., 2002), conservation is underfunded everywhere, with the shortfall in resources needed to do the job properly being particularly extreme in developing countries. For example, while developed world expenditure on terrestrial reserves runs at only around one third of the estimated requirement for an

Andrew Balmford (Corresponding author) Conservation Biology Group, Department of Zoology, University of Cambridge, Downing Street, Cambridge, CB2 3EJ, UK. E-mail: apb12@hermes.cam.ac.uk

Tony Whitten The World Bank, 1818 H St NW, Washington, DC, 20043, USA.

Received 6 December 2002. Revision requested 12 February 2003. Accepted 7 April 2003. effective network (covering c. $15 \%$ of land area), in the developing world current expenditure is reckoned, roughly, to be less than one twentieth of that needed (James et al., 1999a; Balmford et al., 2003; Fig. 1b).

Bridging this gap represents a major and urgent challenge to those interested in tropical conservation. How can we bring about a substantial and sustained increase in the funds available for developing country conservation in ways that are both ethically acceptable (with those who benefit most from conservation paying most for it), and pragmatic (with those targets identified being plausible sources of increased support)? Money is by no means the sole obstacle to achieving conservation and not all money already available is used as efficiently as it could be. Nevertheless, we contend that many opportunities for better conservation are lost through inadequate funding (see for example, LeaderWilliams \& Albon, 1988) and that many of the poorest and biologically richest countries are dependent on greatly increased funding for the sustained conservation of their often large, diverse and highly-pressured protected areas.

In this paper we explore two aspects of how we may respond to this challenge. We start by considering how in principle the shortfall in support for tropical conservation ought to be met. Building on earlier arguments of Bell (1987), Wells (1992) and Kramer and Sharma 

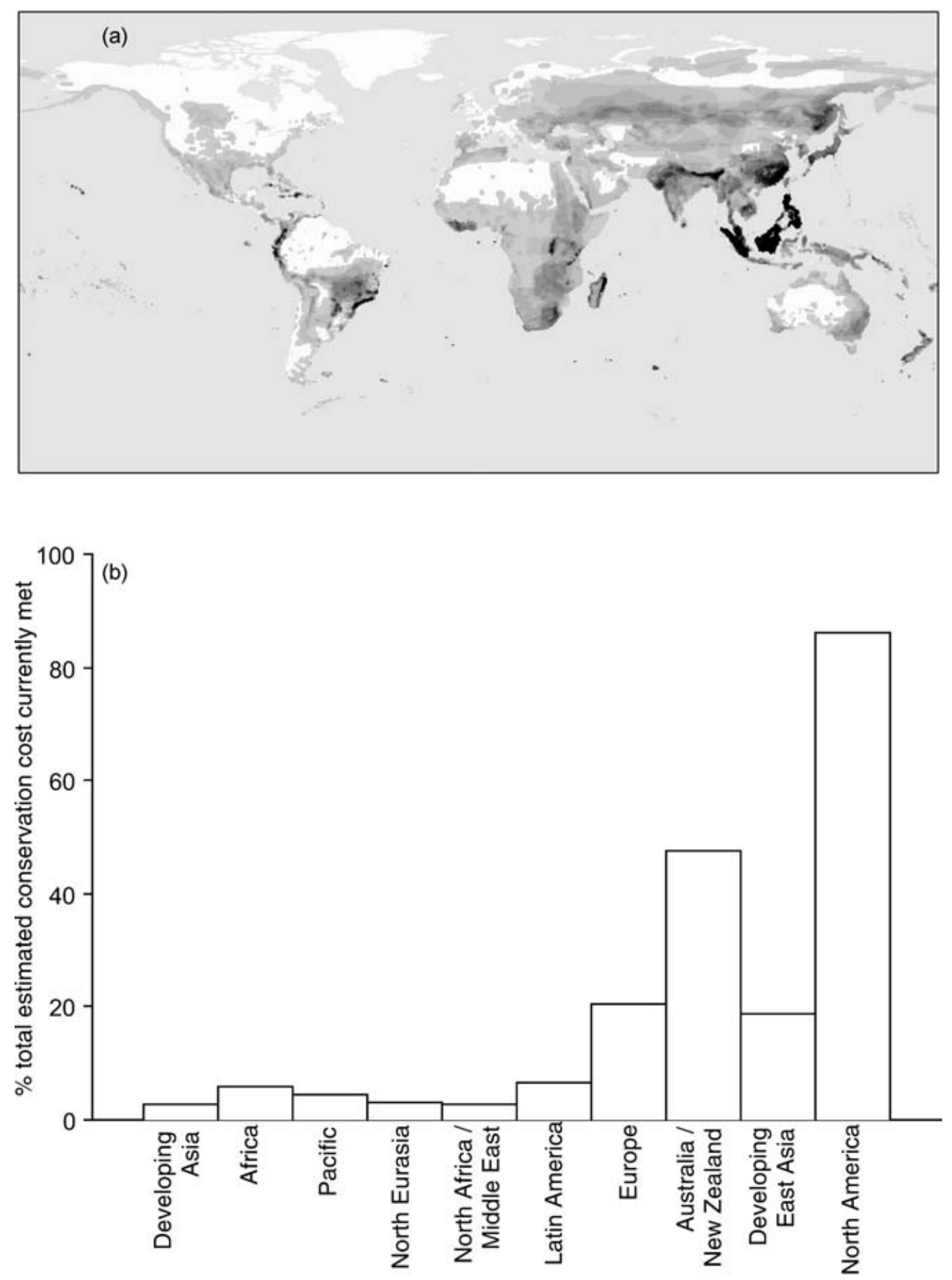

Increasing regional mean per capita income

Fig. 1 (a) The density of threatened bird species across $1 / 4^{\circ}$ grid squares of the globe, highlighting the importance of the tropics; the darkest shade represents 16-25 species (reproduced, with permission, from BirdLife International, 2000, courtesy of M. Balman). (b) Variation in the extent to which the total direct costs of terrestrial reserve networks (effectively conserving 15\% of different regions) are currently met, vs mean per capita income (from Balmford et al., 2003). 
(1997), we examine how the costs and benefits of conservation are presently distributed across local, national and global stakeholders. Who pays for conservation at the moment, and where do different types of benefit accumulate? We argue that in principle each constituency should meet the necessary increases in funding in approximate proportion to the value of the benefits it receives from conservation. In the second part we then use these insights into the distribution of conservation benefits and current conservation spending as a context for exploring where in particular the extra investment may come from. What do recent developments tell us about the scope for increased support from private donors, from business, and from taxpayers, and are there other means by which the gap between conservation needs and current support can be narrowed?

We do not attempt to tackle other major hurdles to tropical conservation, such as the chronic shortage of trained conservation professionals, the need to expand in-country public and political support for conservation, and the need to develop institutions capable of delivering conservation benefits effectively and equitably on the ground. These are all extremely important issues, but are beyond our scope here. In addition, our own experience means that our focus in this essay is on protected areas, particularly on land. However, while the detailed distributions of conservation costs and benefits will be different for aquatic systems and for nonreserved land, and will vary across individual terrestrial reserves, we believe that our overall conclusions are broadly applicable.

\section{Who in principle should pay?}

Consider three groups of stakeholders (after Wells, 1992): local people, living in or near the area targeted by a conservation intervention such as a park, the national community, which includes locally-based commercial elites but consists mainly of more distant stakeholders, and the global community of concerned individuals, businesses, non-governmental organizations (NGOs), governments and inter-governmental organizations. How much do each of these constituencies currently pay for conservation?

\section{Who pays for conservation now?}

In addressing this question, it is helpful to think about two classes of cost: the immediate costs of conservation activities, including the costs of acquiring or leasing land, managing or restoring habitats and populations, and enforcing restrictions on land use, which we term active costs; and the indirect costs of conservation, which we term passive costs, and which include the opportunity costs that arise when harvesting wild populations or converting wild habitats is restricted, as well as the costs of damage by animals originating in conserved habitats. Although some active and passive costs (such as the budget for running a national parks' head office, or the opportunity costs to international consumers of reduced harvesting of protected species) are located at national or global levels, most costs are located in or near to the areas targeted by a project. The question is, who currently pays those costs?

Considering firstly the active costs of conservation programmes in developing countries, these are generally met in the main by state or national agencies and, to a lesser extent, NGOs funded by a combination of national and international level taxpayers and donors (upper row, Fig. 2). According to surveys of national protected area agencies conducted by the UNEP-World Conservation Monitoring Centre in 1993 and 1995, international donors funded only c. $20 \%$ of total expenditure on developing country nature reserves (James et al., 1999b). However, James et al. (1999b) suggest this was a substantial underestimate, a point confirmed by comparison with a topdown analysis of international donor investment in Latin America and the Caribbean from 1990 to 1997 (Castro et al., 2000b). Castro et al. (2000) report that international donors spent at least \$180 million annually on protected areas in Latin America and the Caribbean at a time when equivalent government expenditure was probably <\$150 million per year (James et al., 1999a, $1999 \mathrm{~b}$; note that these and all other costs have been updated to year 2000 US \$, and that by 'billion' and 'trillion' we mean $10^{9}$ and $10^{12}$, respectively). Hence
Local

\section{O}

Active costs
National Global

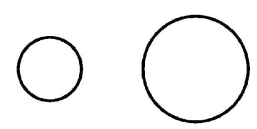

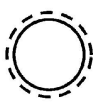

Passive costs

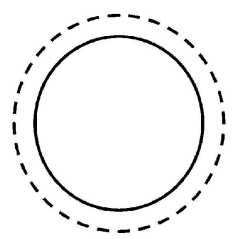

Fig. 2 A rough schematic of the current distribution of the costs of conserving protected areas in developing countries. In the upper row, the area of the circles describes the approximate relative contribution of local, national and global communities to current expenditure on the direct costs of tropical reserves (estimated at c. $\$ 750$ million annually; James et al., 1999a). In the lower row, the area of the circles describes the current distribution of passive costs; actual costs (solid lines) may be lower than perceived costs (dashed lines) because current levels of use of natural habitats may not be sustainable. 
although data are limited, for Latin America and the Caribbean at least, it appears that international funding for the active costs of conservation is probably greater than national-level outlay. Payments by local communities, on the other hand, are generally limited to tax contributions, which because of widespread rural poverty are low in absolute terms.

In contrast, we consider that local communities probably bear the brunt of the passive costs of developing country conservation (lower row, Fig. 2) because the private benefits foregone as a result of the establishment of a protected area (through restrictions on harvesting wild species, lost opportunities to convert wild habitats to farms or plantations, or reduced prospects of development of new infrastructure such as roads or electricity) can be substantial (Wells, 1997; Balmford et al., 2002). In Madagascar the opportunity costs of two parks to villagers that harvest wild resources have been estimated at between \$39 and \$125 per household per year (Kramer \& Sharma, 1997; Ferraro, 2001), while in a third area abandoning slash-and-burn agriculture and harvesting would cost upland households between $\$ 93$ and $\$ 191$ per year (Brand et al., 2002); these costs probably represent over $10 \%$ of household income (Ferraro, 2001). In Kenya the gross opportunity costs of the country's c. $60,000 \mathrm{~km}^{2}$ of parks and reserves have been estimated at $\$ 270$ million annually (Norton-Griffiths \& Southey, 1995). For developing countries as a whole, one upper estimate (based simplistically on the value of land in strictly protected areas) puts the opportunity costs of existing reserves at $>\$ 5$ billion each year - approaching an order of magnitude more than the c. $\$ 750$ million currently spent by all agencies combined on meeting their direct costs (James et al., 1999a, 2001; Table 1).

Most of these costs are met by local people (Bell, 1987; Wells, 1992; Kramer \& Sharma, 1997; Ferraro, 2001; Brand et al., 2002). Added to this, local communities in some areas can bear significant costs as a result of animals

Table 1 Approximate estimates of the likely total annual costs of a protected area network covering c. $15 \%$ of tropical land area. Note that figures become increasingly imprecise from top to bottom; all figures are in year 2000 US \$. For estimation details, see James et al., 1999a, b, 2001).

\begin{tabular}{ll}
\hline Costs & \$(million per year) \\
\hline Active & \\
Current expenditure on existing reserves & c. 750 \\
Shortfall in current expenditure & c. 1,500 \\
Management costs of additional & \\
reserves, needed to reach $15 \%$ target & c. 2,000 \\
Passive & \\
Opportunity costs of existing reserves & c. 5,000 \\
Opportunity costs of additional reserves & c. 6,500 \\
\hline
\end{tabular}

from conservation areas damaging crops, killing livestock and even killing people (Karanth \& Madhusudan, 2002). Conservation initiatives can also impose opportunity costs at national scales (for example through lost tax revenue from logging operations; Kremen et al., 2000), and at an international level (through reduced exploitation of species in international trade). In addition, passive costs that are locally incurred may be partially transferred to national or, more commonly, international levels by the provision of compensation schemes or alternative development programmes.

Three other points need highlighting at this stage:

1. While the passive costs of conservation are often significant at the local level, they are sometimes perceived to be even greater than they actually are (see dashed circles in Fig. 2) because some particularly destructive uses of natural habitats (such as blast fishing) may not be sustainable even in the short term. The opportunity costs of conservation are also sometimes inflated by incentive schemes which subsidise otherwise uneconomic habitat conversion (Myers, 1998; van Beers \& de Moor, 1999; Myers \& Kent, 2001).

2. However, the local communities most strongly affected by the passive costs of developing country conservation are generally among the poorest of the poor; it is both inequitable and impractical to expect them to continue to bear these costs into the future (Bell, 1987; Wells, 1992; Norton-Griffiths \& Southey, 1995; Kramer \& Sharma, 1997; Ferraro, 2001).

3. Fig. 2 is based on the current costs of existing terrestrial reserves. Yet despite some successes (Bruner et al., 2001) many tropical protected areas are deteriorating (van Schaik et al., 1997; Brandon et al., 1998; Oates, 1999; Terborgh, 1999; Terborgh et al., 2002), and reserve managers estimate that roughly another $c$. $\$ 1.5$ billion is needed annually to meet the full active costs of these reserves (James et al., 1999a, 1999b; Table 1). Added to this, total reserve extent is far below the c. $15 \%$ of land area considered as a minimum safe standard for conserving a representative sample of species, habitats and ecosystem services over the medium- to long-term (IUCN, 1993, 1998). Expanding developing country reserve networks to meet this target has been very roughly estimated to cost an extra $c$. $\$ 2$ billion each year in active costs, plus c. $\$ 6.5$ billion annually to offset local opportunity costs (James et al., 1999a, 2001; Table 1). We know far less about the costs of marine reserves, but as they cover less than 1\% of marine area (Kelleher et al., 1995), these too will also require dramatically increased funding over the next few decades (Balmford, unpub.).

Given the enormous inequities in the current distribution of conservation costs, and the need to spend a great deal more on tropical conservation if it is to succeed, how can we substantially increase conservation 
investments, and do so fairly? We believe the key is to examine the current distribution of conservation benefits, and the potential for these being increased in the future.

\section{Who benefits from conservation?}

Here we consider five classes of benefits that may arise from tropical conservation: sustainable consumption of conserved resources for food, timber and other fibres, and medicines; nature-based tourism; localized ecological services such as regulation of water supply, prevention and reduction of storm and flood damage, and erosion and sedimentation control; more widely dispersed ecological services such as nutrient and climate regulation, and carbon storage; and option, existence and bequest values. Where do these benefits currently accrue, and can they expanded to better offset the costs of conservation?

We contend that where wildlife and wildlife products are not commonly marketed the benefits are generally greatest at the local level (top row, Fig. 3). However, for that subset of these products that are marketed, the benefits at national scales can be substantial, and are generally less significant, though nevertheless important in some cases, at the international level. Efforts to make existing harvesting regimes sustainable, to expand

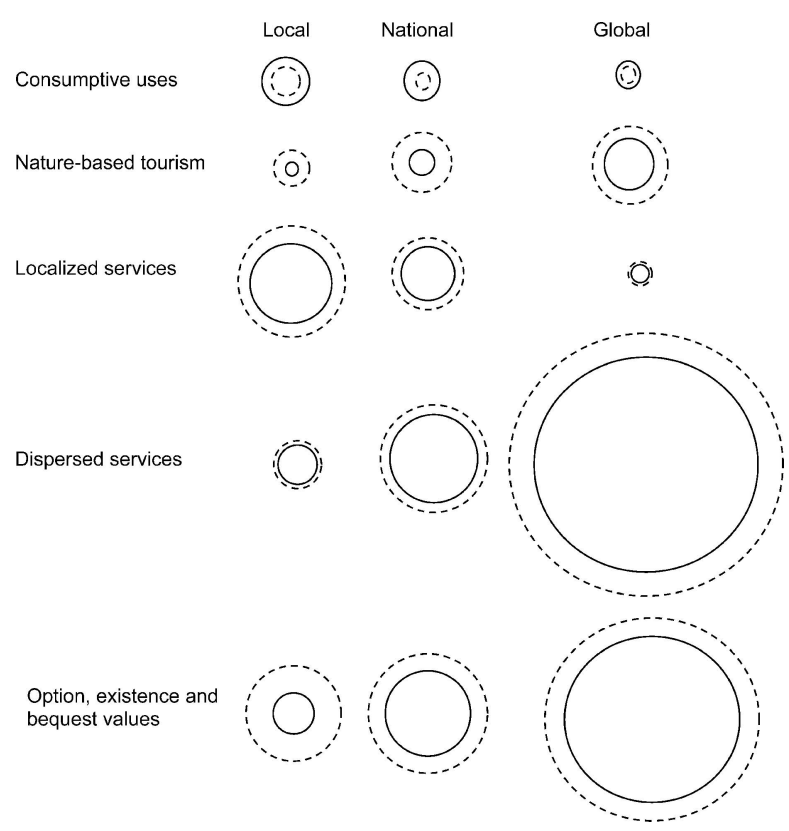

Fig. 3 A rough schematic of the current distribution of five kinds of benefits from developing country conservation. In each row, the area of the solid circles describes current benefits, while the area of the dashed circles describes potential, sustainable benefits in future The total size of a row's circles reflects that benefit's approximate total value, relative to other benefits (from Costanza et al., 1997). harvesting to other species, and to identify new markets lie at the core of many recent attempts to simultaneously offset the local opportunity costs of conservation and achieve development goals (IUCN/UNEP/WWF, 1980, 1991; Reynolds et al., 2001). However, there is a growing view that while it can work in some situations, this 'use-it-or-lose-it' approach will frequently lead to the over-exploitation of wild resources, if not immediately, then as human populations and demands rise (Redford, 1992; Robinson, 1993; Barrett \& Arcese, 1995; Brandon, 1997; Kramer et al., 1997; Brandon et al., 1998; Newmark \& Hough, 2000; van Schaik \& Rijksen, 2002). For this reason we suggest that current levels of consumptive benefits from tropical reserves may not be sustainable, and will inevitably become lower in future, as stocks are depleted or permitted harvests are reduced (dashed circles in upper row, Fig. 3).

Nature-based tourism is also often advocated as a promising means of deriving substantial benefits from conservation (Boo, 1992; Goodwin, 1996; Davenport et al., 2002). However, in most cases the benefits of tropical nature-based tourism accumulate largely at national and especially international levels, rather than offsetting opportunity costs at the local level (Brandon, 1996; Wells, 1997; second row, Fig. 3). A study from Royal Chitwan National Park in Nepal, for example, reported that only $6 \%$ of households living nearby obtain any income directly or indirectly from the 50,000-100,000 people visiting the park each year (Bookbinder et al., 1998). Likewise, only $0.2 \%$ of the total expenditure by tourists visiting Komodo National Park in Indonesia has until recently accrued to local villages adjacent to the park (Walpole \& Goodwin, 2000). Tourism is also extremely sensitive to periods of political instability. In central Africa, for instance, lucrative gorilla tourism in Rwanda and the Democratic Republic of Congo plummeted following civil wars (Butynski \& Kalima, 1998) and Uganda's tourist industry has yet to recover from its collapse during Idi Amin's presidency, which ended over 20 years ago. These impacts of war can be more long-lasting than those on core conservation activities (Hart et al., 1996). There is evident scope for the benefits of nature-based tourism to be increased, both in general (tourism is currently the world's fastest growing industry, with nature-based tourism believed to be its fastest growing sector, Davenport et al., 2002) and through targeted efforts to increase revenue-sharing, especially at the local level (Walpole \& Goodwin, 2000; Walpole \& Leader-Williams, 2001). Nevertheless, many biodiverse habitats and wild destinations are simply too remote, too dangerous, or insufficiently charismatic to attract large numbers of high-paying tourists (McClanahan, 1999; Davenport et al., 2002). We therefore consider that the potential for expanding nature-based tourism and 
its benefits for conservation is more limited than sometimes suggested (Boo, 1992; Goodwin, 1996; Davenport et al., 2002; dashed circles in second row, Fig. 3).

The conservation of wild habitats can generate substantial, though commonly underappreciated, benefits through the provision of localized ecological services (third row, Fig. 3). For example, retaining forest cover can reduce the risks of downstream flooding, erosion and sedimentation, while maintaining dry season water flows through evapotranspiration and cloud interception; likewise, coral reefs and mangroves act as nurseries for offshore fisheries, and absorb storm energy, thereby protecting coastal communities (for examples see: Kumari, 1994; Sathirathai, 1998; Becker, 1999; White et al., 2000; Yaron, 2001; Turner et al., 2002). These benefits mostly accrue at the local level, although in many developing countries the provision of such services to major urban centres is dependent on the maintenance of upstream forest cover (McNeely, 1988; Burgess et al., 2002; Spergel, 2002). At all scales the value of these services is likely to increase as human populations grow, become wealthier, and disperse into previously unoccupied areas near patches of intact habitat (dashed circles in third row, Fig. 3).

For present purposes, dispersed ecological services are those whose benefits can be enjoyed at a considerable distance from the conserved habitat. For example, because atmospheric carbon circulates globally, the contribution of a conserved wetland or forest to carbon sequestration or storage benefits everyone. While again underappreciated, such services can be tremendously valuable (Myers, 1996; Costanza et al., 1997; Daily, 1997; Pimentel et al., 1997), especially at the global scale, where they contribute to the welfare of large numbers of relatively wealthy people (fourth row, Fig. 3). The value of dispersed ecological services is likely to grow as human populations increase and per capita incomes rise (dashed circles).

We turn last to an array of non-use values (bottom row, Fig. 3): those arising from retaining the possibility of use in the future (option values), those that describe the value of simply knowing a habitat or species is still extant (existence values), and those that derive from being able to pass on those benefits to future generations (bequest values). These values have informed traditional views of the relationship between people and nature in many parts of the world, but are notoriously hard to capture in monetary terms (OECD, 2002), although their lower bounds are represented by the donations to conservation NGOs. Again, higher average wealth and total population size mean that in absolute terms these benefits are greater at national than local scales, and greatest of all at the global level. They can be expected to grow as people become wealthier and more numerous.
They may also increase as natural habitats become scarcer, and if people become more aware of their natural heritage.

\section{So who should pay?}

Comparing these distributions of benefits and costs yields several broad insights into who ought to pay for tropical conservation:

1. A simple 'fortress-and-fines' approach for imposing conservation on local people without due compensation or opportunities for participation is, in our view, not only immoral (in suggesting that sizeable opportunity costs should be met by the rural poor), but also unworkable in the long-term because, as populations grow, the rising costs of enforcement would further increase the largely unmet active costs of conservation.

2. Solutions which meet local opportunity costs may also fail when they rely on expanding already unsustainable resource exploitation, or on substantially increasing and redistributing income from nature-based tourism. One important exception here may be many marine reserves, for which evidence is accumulating that the export of fish biomass to surrounding areas can commonly exceed the harvest foregone within a 'no-take' zone (Roberts \& Hawkins, 2000; Roberts et al., 2002).

3. The unmet passive and active costs of tropical conservation will instead often have to be met from other benefit streams (see also Wells, 1992; Kramer \& Sharma, 1997; Sinclair et al., 2000; Terborgh \& Boza, 2002). The increase in funding needed is so great that many new funding sources need to be identified, across all scales (Turner et al., 2002). Moreover, because for some habitats the costs of conservation at the local level may exceed the local benefits, cross-subsidy between scales may sometimes be necessary (J. Kellenberg, pers. comm.; see Plate 1 for an example). Spreading responsibility for meeting the costs of conservation across beneficiaries should also buffer conservation activities against economic fluctuations in individual countries or sectors.

4. In general, the most promising sources of increased support will be those constituencies that already gain the most from conservation (i.e. the columns with the biggest solid circles in Fig. 3), and those whose benefits are likely to grow most in future (i.e. those with dashed circles much larger than solid circles). Looking from left to right across Fig. 3 at the relative magnitude of the overall benefits enjoyed by each group of stakeholders, the greatest contribution to meeting the currently unmet costs of tropical conservation should come from the global community, followed by national and then local stakeholders. Because the developed world and, to a lesser degree, urban communities of developing countries 


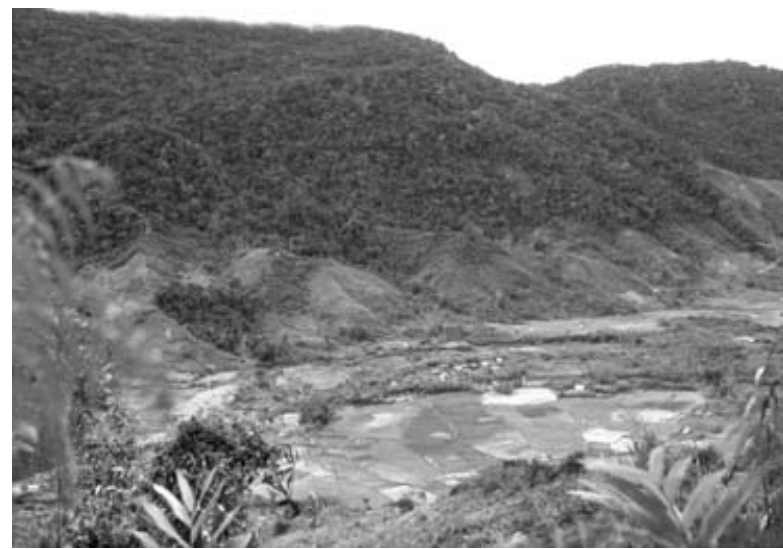

Plate 1 Lowland rice farming below upland forests in eastern Madagascar. Lowland farmers will benefit if upstream forest clearance is reduced, because of reduced flooding and sedimentation in their paddies. However, a contingent valuation study suggests lowland farmers' willingness to pay for upland conservation is far lower than the opportunity costs to upland farmers of abandoning slash-and-burn agriculture (Brand et al., 2002). Other beneficiaries of conservation must meet these costs if Madagascar's upland forests are to be conserved effectively and equitably.

gain most from tropical conservation, it is only equitable and practical that they should pay the bulk of the costs for it; at present they do not (see also Wells, 1992; Norton-Griffiths \& Southey, 1995; Kramer \& Sharma, 1997; Turner et al., 2002).

5. Turning from columns to rows in Fig. 3, the largest conservation benefits accrue not, as sometimes supposed, from direct consumption or nature-based tourism, but from localized and dispersed services, and from nonuse values (see also Costanza et al., 1997). Accordingly, it is these benefit streams which best justify expanded support for tropical conservation, and which may be most readily tapped to provide new conservation funding. However, because such benefits are by and large non-rival and non-excludable, persuading beneficiaries to invest in conservation to secure the benefits over the longterm will commonly require government intervention.

6. The idea of national and global beneficiaries of ecosystem services and existence values paying local communities for their continued delivery raises several potentially difficult issues. We would argue, however, that most are soluble and none is unique to this model of conservation funding. For example, payment to not harvest or not convert raises worries about welfare dependency. However, communities could be required to be active in ensuring compliance with conservation objectives (Ferraro \& Kiss, 2002), and payments could be in kind (for example, through the provision of clinics or schools), rather than in cash (Ferraro \& Kramer, 1997). A related problem is that the provision of payments may stimulate immigration from elsewhere, increasing both costs and pressures (for examples, see Campbell and Hofer, 1995; Merlen, 1995; Oates, 1999). But such a 'honeypot' effect can be a problem for any scheme which seeks to address rather than ignore the passive costs of conservation, and can only be tackled through the early establishment of who does and does not have rights to compensation (Ferraro \& Kramer, 1997). Finally, mechanisms for delivering compensation need to be both equitable and effective. Payments should reach all those incurring opportunity costs, and should probably be delivered not as a lump sum but in a continuous stream, in direct exchange for ongoing production of conservation benefits (Ferraro \& Kiss, 2002; Ferraro \& Simpson, 2002).

In summary, our cost-benefit comparison suggests that a great deal of the increased support needed for tropical conservation should come from global stakeholders, in exchange in particular for the continued delivery of both dispersed ecological services and existence values (see also Wells, 1992; Ferraro \& Simpson, 2002; Hardner \& Rice, 2002). The central challenge will be how to bring these less tangible benefits to the attention of decision-makers.

\section{How can we bridge the gap in practice?}

Having examined the principles of who ought to pay for tropical conservation and why, we now turn to thinking about where in practice the extra funds may be raised. Of course the magnitude of the shortfall in funding means that we need to cast our net widely. We must look for increased support from local and national as well as global communities, via a mix of mechanisms: increased individual donations, bringing the market to bear, and expanding direct contributions from governments.

\section{Increased donations}

At one end of the spectrum, increasing numbers of private individuals are joining membership NGOs (Fig. 4). The rise of new, tropically-based NGOs, albeit patchy, is encouraging (although their most important contributions may be political, educational and practical, rather than financial). At the other end of the spectrum, the last 5 years have seen a dramatic increase in the size and number of major contributions to tropical conservation from private individuals and foundations (for an example of a single initiative totalling \$261 million, see Conservation International, 2001). Likewise, large corporations, mostly, but not exclusively, involved in primary industries, have made a number of extremely significant donations in recent years (for one new $\$ 50$ 


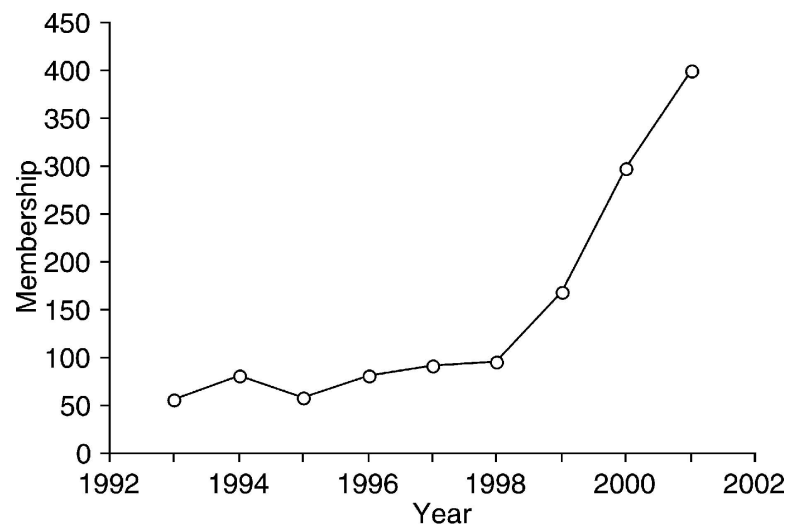

Fig. 4 Recent growth of NatureUganda, a local membership NGO. Data kindly provided by NatureUganda.

million partnership, see Investing in Nature, 2003). These are welcome and encouraging moves, and it is to be hoped that they in turn catalyse further contributions. Nevertheless, even these unprecedently large donations can feasibly provide only a fraction of the total resources needed, and all NGOs are currently suffering from reduced donations as a direct result of the battered stock market.

\section{Bringing markets to bear}

A broad suite of exciting new initiatives for funding conservation is also emerging from the commercial sector (Chichilinsky \& Heal, 1998; Daily \& Walker, 2000; Daily \& Ellison, 2002; Sandor et al., 2002). Some are essentially extensions of existing markets, and operate through global-level consumers choosing to invest in environmentally responsible companies or paying premium prices for certified products that have been sustainably harvested (see, for example, Forest Stewardship Council, 2003, Marine Stewardship Council, 2003, Marine Aquarium Council, 2003, and Project Piaba, 2003). Again, these developments are extremely welcome, but they may inevitably only ever capture a fraction of the developed world market (and less of the developing world market), and their main role probably lies in the sustainable management of resources beyond reserves, rather than in financing protected areas (Hardner \& Rice, 2002).

Other market-based initiatives involve creating entirely new markets through which beneficiaries pay producers for the provision of ecosystem services; in many cases, the prompt for beneficiaries to pay for what they have previously received for nothing has come from new legislation. The most developed such market is for watershed protection. In Colombia, Ecuador and Laos hydroelectric companies are handing over a substantial portion of their revenues for upstream forest conser- vation; similar payments are made by downstream water consumers in Ecuador, and by municipal authorities in El Salvador (Kiss et al., 2002; Spergel, 2002).

More ambitious programmes are underway to try to secure funding for conservation through carbon credit schemes. These have considerable potential to generate significant sums for conserving tropical forests, particularly as developing countries generally have a comparative advantage, in being to able to achieve credible emissions reductions at far lower marginal cost than developed nations (Kiss et al., 2002; Niesten et al., 2002; Niles et al., 2002). However, there is at present a major hurdle. Although reducing ongoing conversion of natural forests could make a large contribution towards meeting lowered $\mathrm{CO}_{2}$ emission targets agreed under the Kyoto Protocol (Malhi et al., 2002), concerns over confirming compliance and over the validity of forest conservation as a carbon sequestration instrument mean that, at present, habitat retention is not eligible for carbon credits under the Clean Development Mechanism of the United Nations Framework Convention on Climate Change (Bonnie et al., 2002; Niles et al., 2002).

Other means of funding conservation through paying for carbon storage are possible, however. Internet-based initiatives run by organizations such as Climate Care (2003) and Future Forests (2003) enable individuals or organizations to make voluntary payments in proportion to their carbon emissions, with revenues funding, among other things, tropical conservation projects. The World Bank has just launched the $\$ 100$ million BioCarbon Fund (World Bank, 2003) with the aim of reducing greenhouse gases in the atmosphere while reversing land degradation and the loss of biodiversity, and improving local livelihoods in poor countries. In Costa Rica a national tax on petrol has funded annual payments to landowners of $c$. $\$ 40$ per hectare for retaining and managing natural forests (Castro et al., 1998). Since $1997,320,000$ hectares have been brought into this programme (MacKinnon et al., 2002). This funding base is now being expanded through contributions from hydroelectric companies for hydrological services and tourism operators for provision of biodiversity and scenic beauty (Chomitz et al., 1999; Kiss et al., 2002; see Plate 2).

\section{Expanding direct government contributions}

Despite the encouraging and significant growth in funding for conservation from private donors and markets, we believe that general taxes, raised by governments, will continue to be the principle means by which tropical conservation is financed, and by which the funding gap may be bridged (James et al., 2000). Although the total costs of effectively conserving a representative sample of tropical wild nature are vast (of the order of $\$ 16$ 


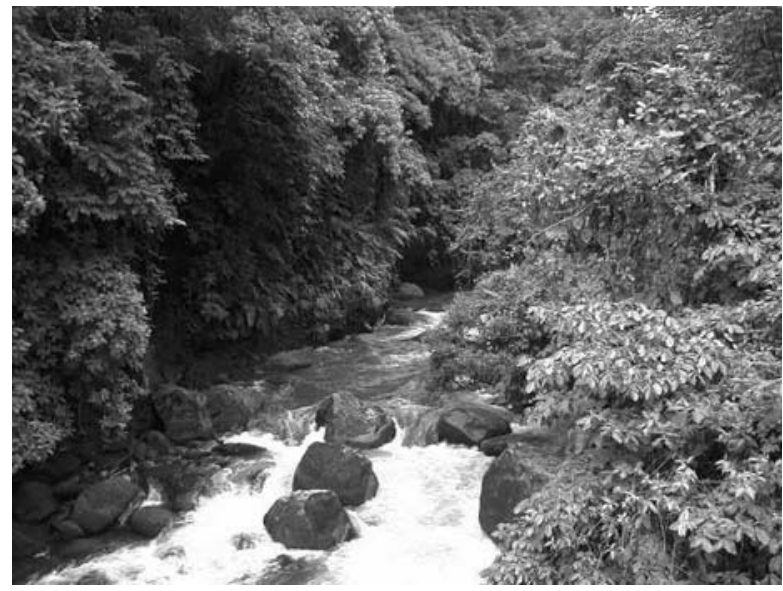

Plate 2 Costa Rican forests such as this deliver a range of localized and dispersed services; new initiatives are now capturing some of these values and making payments to land-holders who retain native forest cover (Castro et al., 1998; Chomitz et al., 1999; Kiss et al., 2002; MacKinnon et al., 2002). Photo courtesy of J. Kellenberg.

billion annually for terrestrial reserves, for example; James et al., 1999a, 2001) - they represent only a tiny proportion of global GDP or tax revenue (c. $0.05 \%$ and c. $0.2 \%$, respectively; World Bank, 2002). However, while donor governments do already make major contributions to tropical conservation, there is little evidence that this support has grown significantly since the first commitments to the Global Environment Facility in the early 1990s (Castro et al., 2000a; Horta et al., 2002; MacKinnon et al., 2002). The Global Environment Facility has been a major new source of financing for conservation but its remit has been extended to include land degradation and persistent organic pesticides with the result that the funds available for conservation and the other original programmes must inevitably be reduced. External funding is of course complemented by sizeable co-financing contributions from the tropical governments themselves in addition to the provision of recurrent costs. Under debt-for-nature swaps, increased conservation investment can relieve developing world governments of some of their debt repayments (see Spergel, 2002, for a recent review), although such initiatives could be undermined by programmes of debt relief for the poorest countries.

For donor governments, sizeable increases in conservation funding could be achieved through various means. Though it may appear naïve, we believe it is worth reiterating that all conservation needs could be readily met through only moderate reductions in military spending: a pertinent comparison given that environmental security is likely to be at least as important an issue over the 21st century as national security (Raven, 2002). A globally effective conservation programme could be funded for less than President Bush's recent increases in annual US military expenditure alone. Alternatively, the necessary funding could come from eliminating just a small fraction of the c.\$1-2 trillion currently spent each year on 'perverse' subsidies that simultaneously harm the environment and encourage economic inefficiency (Myers, 1998; van Beers \& de Moor, 1999; Myers \& Kent, 2001); this would have the added benefit, in many cases, of reducing pressures on remaining habitats and lowering the local opportunity costs of conservation (see above). One other possibility is for northern governments to fund conservation by raising entirely new taxes (Spergel, 2002). One recurring suggestion is a so-called Tobin tax on the $c$. $\$ 2$ trillion traded each day by currency speculators. A tax of $0.1-0.25 \%$ may help suppress harmful currency speculation while raising c. \$100-300 billion annually for international environmental and poverty-related issues (Tobin Tax Initiative, 2003; Global Policy Forum, 2001). An unavoidable challenge, however, for any proposal to significantly increase donor governments' expenditure on conservation in the developing world, is that, unlike military spending, perverse subsidies, or even development aid, such a commitment would require the north-south transfer of real financial resources. The response to this challenge, of course, is to point out that such a transfer is entirely justified, given the substantial flow of conservation benefits in the opposite direction (Fig. 3).

It should be noted that all countries are now committed to achieving the eight United Nations Millennium Development Goals (United Nations, 2000). While only one of these explicitly refers to the environment, the Water, Energy, Health, Agriculture and Biodiversity framework used at the World Summit on Sustainable Development in 2002 reveals the interaction between biodiversity and the other Millennium Development Goals that cover poverty, hunger, health, water, sanitation, education and the means of executing development (IISD, 2003). This should mean that biodiversity receives more attention and is 'mainstreamed' in the course of development, especially in the productive landscape.

\section{Four final considerations}

This review of the practicalities of meeting the gap in funding tropical conservation raises four other issues that are crucial but cannot be dealt with at length here.

1. If the recurrent costs of conservation cannot be adequately met though resource exploitation or naturebased tourism but instead require payments to local communities from elsewhere, those payments must be made on a recurrent, long-term, basis. While the fixed term "...project format is appropriate for building a bridge, constructing a dam, or even subduing an outbreak of infectious disease ... it is entirely inappropriate 
for conserving nature" (Terborgh \& Boza, 2002, building on Wells et al., 1999; see also Janzen, 1986; Sinclair et al., 2000; Ferraro \& Kiss, 2002). Ongoing, market-based payments offer one route to recurrent funding. A second is via the establishment of conservation trust funds, which may variously pay for conservation simply from the interest on their endowment, or by drawing down a large capital sum over time (Spergel, 2002). Although it can often prove difficult to attract donors for the heavily front-loaded support that these schemes require, they have been successfully established in Uganda, Malawi, Bhutan, Bolivia, Brazil, Peru and Mexico (MacKinnon et al., 2002).

2. There is a perceived gap between the funding of conservation NGOs and the funding of conservation action on the ground. Both the NGOs and donors are sensitive to this and there is a growing and unprecedented cooperation developing among the main conservation NGOs to assess the effectiveness of their programs and thereby to improve their delivery. This requires better setting of targets, making meaningful measurements of change, and learning from the results (Salafsky et al., 2002). In addition a tool has been developed to assess the effectiveness of protected areas (Hocking et al., 2000), a version of which is being applied to all World Bank, Global Environment Facility, and WWF forest and biodiversity projects (Stolton et al., in press).

3. While we have concentrated on how to increase the funds available to meet conservation costs, other initiatives are also important. For example, research and dissemination of results on the local delivery of ecosystem services by natural habitats, and the growing awareness of the connections between the major faiths and conservation (Prance, 1996; Ramakrishnan et al., 1998; Posey, 1999; Goldsmith, 2000; Biodiversity Project, 2002) can greatly increase a community's awareness of the imperatives and benefits of conservation. This can offset their perception of the opportunity costs it incurs, and in turn lower the active costs of enforcing conservation regulations (for an encouraging example, see Becker, 1999). Likewise, locally relevant environmental education, the growth of local NGOs, and the development of nature-based tourism aimed at local and national communities (helped, for instance, by local language fieldguides and by lower park entry fees for nationals) can all increase the non-use and localized-service values of conservation areas, raise in-country support for conservation, and hence lower the active costs of conservation (Bell, 1987; Davenport et al., 2002; Dourojeanni, 2002).

4. Finally, there is a need to tackle the thorny issues of accountability, institutional weaknesses and corruption in some host country institutions, none of which is easily dealt with by money alone.

\section{Towards a resolution}

To summarize, the gaps in funding tropical conservation are enormous, and the costs of failing to do so are all too clear. At the risk of sounding fatuous, we note that developed countries alone spend $\$ 17$ billion annually on petfood and $\$ 34$ billion each year on slimming products. It is thus clear to us that the developed world could fund effective conservation in the tropics if it chose to. There are encouraging developments, across several fronts, but an order-of-magnitude gearing-up of current support is nevertheless needed, simultaneous with better use of what we already have to assure donors that their money is making a difference. In our view, this will be achieved only through greatly increased funding from the developed, donor countries, largely via its governments, coupled with greatly increased effort put into working with global, national, and above all, local communities to better understand and disseminate the benefits of conservation. This agenda underscores the global benefits of tropical conservation, and our international responsibilities for meeting its costs.

\section{Acknowledgements}

We thank Mark Balman for preparing Fig. 1a, NatureUganda for the data on Fig. 4, and Monique Borgerhoff Mulder, Agi Kiss, Madhu Rao, Matt Walpole and three anonymous referees for comments on this manuscript.

\section{References}

Balmford, A., Bruner, A., Cooper, P., Costanza, R., Farber, S., Green, R.E., Jenkins, M., Jefferiss, P., Jessamy, V., Madden, J., Munro, K., Myers, N., Naeem, S., Paavola, J., Rayment, M., Rosendo, S., Roughgarden, J., Trumper, K. \& Turner, R.K. (2002) Economic reasons for conserving wild nature. Science, 297, 950-953.

Balmford, A., Gaston, G.J., Blyth, S., James, A. \& Kapes, V. (2003) Global variation in conservation costs, conservation benefits, and unmet conservation needs. Proceedings of the National Academy of Sciences, USA, 100, 1046-1050.

Barrett, C.B. \& Arcese, P. (1995) Are Integrated ConservationDevelopment Projects (ICDPs) sustainable? On the conservation of large mammals in sub-Saharan Africa. World Development, 23, 1073-1084.

Becker, C.D. (1999) Protecting a Garúa forest in Ecuador: the role of institutions and ecosystem valuation. Ambio, 28, 156-161.

Bell, R.H.V. (1987) Conservation with a human face: conflict and reconciliation in African land use planning. In Conservation in Africa: People, Policies and Practice (ed. D. Andersen \& R. Grove), pp. 79-101. Cambridge University Press, Cambridge, UK. 
Biodiversity Project (2002) Ethics for a Small Planet: A Communications Handbook on the Ethical and Theological Reasons for Protecting Biodiversity. Biodiversity Project, Madison, USA.

BirdLife International (2000) Threatened Birds of the World. Lynx Editions, Barcelona, Spain.

Bonnie, R., Carey, M. \& Petsonk, A. (2002) Protecting terrestrial ecosystems and the climate through a global carbon market. Philosophical Transactions of the Royal Society of London Series A, 360, 1853-1873.

Boo, E. (1992) The Ecotourism Boom: Planning for Development and Management. World Wildlife Fund, Washington, DC, USA.

Bookbinder, M.P., Dinerstein, E., Rijal, A., Cauley, H. \& Rajouria, A. (1998) Ecotourism's support of biological conservation. Conservation Biology, 12, 1399-1404.

Brand, J., Healy, T., Keck, A., Minten, B. \& Randrianarisoa, C. (2002) Truths and Myths in Watershed Management: The Effects of Deforestation Upland on Rice Productivity in the Lowlands. FOFIFA, Antananarivo, Madagascar and ILO, Cornell, USA.

Brandon, K. (1996) Ecotourism and Conservation: A Review of Key Issues. World Bank, Washington, DC, USA.

Brandon, K. (1997) Policy and practical considerations in land use strategies for biodiversity conservation. In Last Stand: Protected Areas and the Defense of Tropical Biodiversity (eds R. Kramer, C.P. van Schaik \& J. Johnson), pp. 90-114. Oxford University Press, New York, USA.

Brandon, K., Redford, K.H. \& Sanderson, S.E. (eds) (1998) Parks in Peril: People, Politics, and Protected Areas. Island Press, Washington, DC, USA.

Bruner, A.G., Gullison, R.E., Rice, R.E. \& da Fonseca, G.A.B. (2001) Effectiveness of parks in protecting tropical biodiversity. Science, 291, 125-128.

Burgess, N., Doggart, N. \& Lovett, J.C. (2002) The Uluguru Mountains of eastern Tanzania: the effect of forest loss on biodiversity. Oryx, 36, 140-152.

Butynski, T.M. \& Kalima, J. (1998) Gorilla tourism: a critical look. In Conservation of Biological Resources (eds E.J. MilnerGulland \& R. Mace). Blackwell, Oxford, UK.

Campbell, K. \& Hofer, H. (1995) People and wildlife: spatial dynamics and zones of interaction. In Serengeti II: Dynamics, Management and Conservation of an Ecosystem (eds A.R.E. Sinclair \& P. Arcese), pp. 534-570. University of Chicago Press, Chicago, USA.

Castro, G., Chow, N., MacKinnon, K., Megateli, N., Platais, G. \& Whitten, T. (2000a) Supporting the Web of Life. The World Bank and Biodiversity - a Portfolio Update (1988-1999). World Bank, Washington, DC, USA.

Castro, G., Locker, I., Russell, V., Cornwell, L. \& Fajer, E. (2000b) Mapping Conservation Investments: An Assessment of Biodiversity Funding in Latin America and the Caribbean. Biodiversity Support Program, Washington, DC, USA.

Castro, R., Tattenbach, F., Gomez, L. \& Olson, N. (1998) The Costa Rican Experience with Market Instruments to Mitigate Climate Change and Conserve Biodiversity. Fundecor and MINAE, San José, Costa Rica.

Chichilnisky, G. \& Heal, G. (1998) Economic returns from the biosphere. Nature, 391, 629-630.

Chomitz, K.M., Brenes, E. \& Constantino, L. (1999) Financing environmental services: the Costa Rican experience and its implications. Science of the Total Environment, 240, 157-169.

Climate Care (2003) http:/ / www.climatecare.org [accessed 7 April 2003].
Conservation International (2001) Press Release, 9 December 2001. http:/ / www.conservation.org/xp/CIWEB/ newsroom/press_releases/2001/120901.xml [accessed 7 April 2003]

Costanza, R., d'Arge, R., Groot, R.D., Farber, S., Grasso, M., Hannon, B., Limburg, K., Naeem, S., O'Neill, R.V., Paruelo, J., Raskin, R.G., Sutton, P. \& van den Belt, M. (1997) The value of the world's ecosystem services and natural capital. Nature, 387, 253-260.

Daily, G.C. (ed.) (1997) Nature's Services. Island Press, Washington, DC, USA.

Daily, G.C. \& Ellison, K. (2002) The New Economy of Nature. The Quest to Make Conservation Profitable. Shearwater, Washington, DC, USA.

Daily, G.C. \& Walker, B.H. (2000) Seeking the great transition. Nature, 403, 243-245.

Davenport, L., Brockelman, W.Y., Wright, P.C., Ruf, K. \& Rubio del Valle, F.B. (2002) Ecotourism tools for parks. In Making Parks Work. Strategies for Preserving Tropical Nature (eds J. Terborgh, C.P. van Schaik, L. Davenport \& M. Rao), pp. 279-306. Island Press, Washington, DC, USA.

Dourojeanni, M.J. (2002) Political will for establishing and managing parks. In Making Parks Work. Strategies for Preserving Tropical Nature (eds J. Terborgh, C.P. van Schaik, L. Davenport \& M. Rao), pp. 320-334. Island Press, Washington, DC, USA.

Ferraro, P.J. (2001) The Local Costs of Establishing Protected Areas in Low-Income Nations: Ranomafana National Park, Madagascar. Georgia State University, Atlanta.

Ferraro, P.J. \& Kiss, A. (2002) Direct payments to conserve biodiversity. Science, 298, 1718-1719.

Ferraro, P.J. \& Kramer, R.A. (1997) Compensation and economic incentives: reducing pressure on protected areas. In Last Stand: Protected Areas and the Defence of Tropical Biodiversity (ed. R. Kramer, C.P. van Schaik \& J. Johnson), pp. 187-211. Oxford University Press, New York, USA.

Ferraro, P.J. \& Simpson, R.D. (2002) The cost-effectiveness of conservation payments. Land Economics, 78, 339-353.

Forest Stewardship Council (2003) http: / / www.fscoax.org [accessed 7 April 2003].

Future Forests (2003) http: / / www.futureforests.com [accessed 7 April 2003]

Global Policy Forum (2001) UK at Loggerheads with France Over Tax on Speculators. http:/ / www.globalpolicy.org/socecon/ glotax/currtax/2001/0913uk.htm [accessed 7 April 2003].

Goldsmith, E. (ed.) (2000) Religion in society, nature and the cosmos. Ecologist, 30(1).

Goodwin, H. (1996) In pursuit of ecotourism. Biodiversity and Conservation, 5, 277-291.

Hardner, J. \& Rice, R. (2002) Rethinking green consumerism. Scientific American, 286, 88-95.

Hart, T.B., Hart, J.A. \& Hall, J.S. (1996) Conservation in the declining nation state: a view from eastern Zaire. Conservation Biology, 10, 685-686.

Hocking, M., Stolton, S., Dudley, N. \& Phillips, A. (2000) Evaluating Effectiveness - A Framework for Assessing the Management of Protected Areas. IUCN, Gland, Switzerland.

Horta, K., Round, R. \& Young, Z. (2002) The Global Environment Facility. The First Ten Years - Growing Pains or Inherent Flaws? Environmental Defense, New York, USA and Halifax Initiative, Ottawa, Canada. 
IISD (2003) The Critical Role of Biodiversity \& Ecosystem Services in Achieving the UN Millennium Development Goals. http://www.iisd.ca/linkages/sd/sdund [accessed 7 April 2003].

Investing in Nature (2003) http:/ / www.investinginnature.com/ index.htm [accessed 7 April 2003].

IUCN (1993) Parks for Life: Report of the IVth World Congress on National Parks and Protected Areas. IUCN, Gland, Switzerland.

IUCN (1998) 1997 United Nations List of Protected Areas. IUCN, Gland, Switzerland and Cambridge, UK.

IUCN (2002) 2002 IUCN Red List of Threatened Species. IUCN, Gland, Switzerland [http://www.redlist.org, accessed 7 April 2003].

IUCN/UNEP/WWF (1980) World Conservation Strategy: Living Resource Conservation For Sustainable Development. IUCN/ UNEP/WWF, Gland, Switzerland.

IUCN/UNEP/WWF (1991) Caring For The Earth. A Strategy for Sustainable Living. IUCN/UNEP/WWF, Gland, Switzerland.

James, A., Gaston, K. \& Balmford, A. (1999a) Balancing the earth's accounts. Nature, 401, 323-324.

James, A., Gaston, K. \& Balmford, A. (2000) Why private institutions alone will not do enough to protect biodiversity. Nature, 404, 120.

James, A., Gaston, K. \& Balmford, A. (2001) Can we afford to conserve biodiversity? BioScience, 51, 43-52.

James, A.N., Green, M.J.B. \& Paine, J.R. (1999b) A Global Review of Protected Areas Budgets and Staff. WCMC, Cambridge, UK.

Janzen, D.H. (1986) The future of tropical ecology. Annual Review of Ecology and Systematics, 17, 305-324.

Karanth, K.U. \& Madhusudan, M.D. (2002) Mitigating humanwildlife conflicts in southern Asia. In Making Parks Work. Strategies for Preserving Tropical Nature (eds J. Terborgh, C.P. van Schaik, L. Davenport \& M. Rao), pp. 250-264. Island Press, Washington, DC, USA.

Kelleher, G., Bleakley, C. \& Wells, S. (1995) A Global Representative System of Marine Protected Areas. World Bank, Washington, DC, USA.

Kiss, A., Castro, G. \& Newcombe, K. (2002) The role of multilateral institutions. Philosophical Transactions of the Royal Society of London Series A, 360, 1641-1652.

Kramer, R., van Schaik, C.P. \& Johnson, J. (eds) (1997) Last Stand. Protected Areas and the Defense of Tropical Biodiversity. Oxford University Press, Oxford, UK.

Kramer, R.A. \& Sharma, N. (1997) Tropical forest biodiversity protection: who pays and why. In Last Stand Protected Areas and the Defense of Tropical Biodiversity (eds R. Kramer, C.P. van Schaik \& J. Johnson), pp. 162-186. Oxford University Press, New York, USA.

Kremen, C., Niles, J.O., Dalton, M.G., Daily, G.C., Ehrlich, P.R., Fay, J.P., Grewal, D. \& Guillery, R.P. (2000) Economic incentives for rain forest conservation across scales. Science, 288, 1828-1832.

Kumari, K. (1994) Sustainable forest management in Peninsular Malaysia: towards a total economic valuation approach. $\mathrm{PhD}$ thesis, University of East Anglia, UK.

Leader-Williams, N. \& Albon, S. (1988) Allocation of resources for conservation. Nature, 336, 533-535.

MacKinnon, K., Megateli, N., Platais, G., Whitten, T., Isaac, A., Cassells, D., Douglas, J., Peter, C. \& Gordon, A. (2002) Biodiversity Conservation in Forest Ecosystems. World Bank Assistance 1992-2002. World Bank, Washington, DC, USA.
Malhi, Y., Meir, P. \& Brown, S. (2002) Forests, carbon and global climate. Philosophical Transactions of the Royal Society of London Series A, 360, 1567-1591.

Marine Aquarium Council (2003)

http:/ / www.aquariumcouncil.org [accessed 7 April 2003].

Marine Stewardship Council (2003) http:/ / www.msc.org [accessed 7 April 2003].

McClanahan, T.R. (1999) Is there a future for coral reef parks in poor tropical countries? Coral Reefs, 18, 321-325.

McNeely, J.A. (1988) Economics and Biological Diversity. Developing and Using Economic Incentives to Conserve Biological Resources. IUCN, Gland, Switzerland.

Merlen, G. (1995) Use and misuse of the seas around the Galápagos archipelago. Oryx, 29, 99-106.

Myers, N. (1996) Environmental services of biodiversity. Proceedings of the National Academy of Sciences of the United States of America, 93, 2764-2769.

Myers, N. (1998) Lifting the veil on perverse subsidies. Nature, 392, 327-328.

Myers, N. \& Kent, J. (2001) Perverse Subsidies. How Tax Dollars Can Undercut the Environment and the Economy. Island Press, Washington, DC, USA.

Newmark, W.D. \& Hough, J.L. (2000) Conserving wildlife in Africa: integrated conservation and development projects and beyond. BioScience, 50, 585-592.

Niesten, E., Frumhoff, P.C., Manion, M. \& Hardner, J.J. (2002) Designing a carbon market that protects forests in developing countries. Philosophical Transactions of the Royal Society of London Series A, 360, 1875-1888.

Niles, J.O., Brown, S., Pretty, J., Ball, A.S. \& Fay, J. (2002)

Potential carbon mitigation and income in developing countries from changes in use and management of agricultural and forest lands. Philosophical Transactions of the Royal Society of London Series A, 360, 1621-1639.

Norton-Griffiths, M. \& Southey, C. (1995) The opportunity costs of biodiversity conservation in Kenya. Ecological Economics, 12, 125-139.

Oates, J.F. (1999) Myth and Reality in the Rain Forest. How Conservation Strategies are Failing in West Africa. University of California Press, Berkeley, USA.

OECD (2002) Handbook of Biodiversity Valuation: A Guide for Policy Makers. Organisation for Economic Cooperation and Development, Paris, France.

Pimentel, D., Wilson, C., McCullum, C., Huang, R., Dwen, P., Flack, J., Tran, Q., Saltman, T. \& Cliff, B. (1997) Economic and environmental benefits of biodiversity. BioScience, 47 , 747-757.

Posey, D. (1999) Cultural and Spiritual Values of Biodiversity: A Complementary Contribution to the Global Biodiversity Assessment. UNEP/Intermediate Technology, London, UK.

Prance, G. (1996) The Earth Under Threat: A Christian Perspective. Wild Goose, Glasgow, UK.

Project Piaba (2003) http:/ / www.angelfire.com/pq/piaba [accessed 7 April 2003].

Ramakrishnan, P., Saxena, K.G. \& Chandrashekaran, U.M. (1998) Conserving the Sacred for Biodiversity Management. Oxford, Delhi, India.

Raven, P.H. (2002) Science, sustainability, and the human prospect. Science, 297, 1477.

Redford, K.H. (1992) The empty forest. BioScience, 42, 412-422.

Reynolds, J.D., Mace, G.M., Redford, K.H. \& Robinson, J.G. (eds) (2001) Conservation of Exploited Species. Cambridge University Press, Cambridge, UK. 
Roberts, C.M., Bohnsack, J.A., Gell, F., Hawkins, J.P. \& Goodridge, R. (2002) Marine reserves and fisheries management. Science, 295, 1234-1235.

Roberts, C.M. \& Hawkins, J.P. (2000) Fully -Protected Marine Reserves: A Guide. WWF-US, Washington, DC, USA.

Robinson, J.G. (1993) The limits to caring: sustainable living and the loss of biodiversity. Conservation Biology, 7, 20-28.

Salafsky, N., Margoluis, R., Redford, K. \& Robinson, J. (2002) Improving the practice of conservation. A conceptual framework and research agenda for conservation science. Conservation Biology, 16, 1469-1479.

Sandor, R.L., Bettelheim, E.C. \& Swingland, I.R. (2002) An overview of a free-market approach to climate change and conservation. Philosophical Transactions of the Royal Society of London Series A, 360, 1607-1620.

Sathirathai, S. (1998) Economic Valuation of Mangroves and the Roles of Local Communities in the Conservation of Natural Resources: Case Study of Serat Thani, South of Thailand. Economy and Environment Program for South East Asia, Singapore.

Sinclair, A.R.E., Ludwig, D. \& Clark, C.W. (2000) Conservation in the real world. Science, 289, 1875 .

Spergel, B. (2002) Financing protected areas. In Making Parks Work. Strategies for Preserving Tropical Nature (eds J. Terborgh, C.P. van Schaik, L. Davenport \& M. Rao), pp. 364-382. Island Press, Washington, DC, USA.

Stolton, S., Hocking, M., Dudley, N., MacKinnon, K. \& Whitten, T. (in press) Reporting Progress at Protected Area Sites. World Bank/WWF Forest Alliance, Washington, DC, USA.

Terborgh, J. (1999) Requiem for Nature. Island Press, Washington, DC, USA.

Terborgh, J. \& Boza, M.A. (2002) Internationalization of nature conservation. In Making Parks Work. Strategies for Preserving Tropical Nature (eds J. Terborgh, C.P. van Schaik, L. Davenport \& M. Rao), pp. 383-394. Island Press, Washington, DC, USA.

Terborgh, J., van Schaik, C.P., Davenport, L. \& Rao, M. (ed.) (2002) Making Parks Work. Stategies for Preserving Tropical Nature. Island Press, Washington, DC, USA.

Tobin Tax Initiative (2003) Fact Sheet on Tobin Taxes. http:/ / www.ceedweb.org/iirp/factsheet.htm [accessed 7 April 2003].

Turner, R.K., Paavola, J., Cooper, P., Farber, S., Jessamy, V. \& Georgiou, S. (2002) Valuing Nature: Lessons Learned and Future Directions. CSERGE, University of East Anglia, Norwich, UK.

United Nations (2000) UN Millennium Development Goals. http:/ / www.un.org/millenniumgoals [accessed 7 April 2003].

van Beers, C.P. \& de Moor, A.P.G. (1999) Addicted to Subsidies: How Governments Use Your Money to Destroy the Earth and Pamper the Rich. IOO bv, The Hague, Netherlands.

van Schaik, C.P. \& Rijksen, H.D. (2002) Integrated conservation and development projects: problems and potential. In Making Parks Work. Strategies for Preserving Tropical Nature (eds J. Terborgh, C.P. van Schaik, L. Davenport \& M. Rao), pp. 15-29. Island Press, Washington, DC, USA. van Schaik, C.P., Terborgh, J. \& Dugelby, B. (1997) The silent crisis: the state of rain forest nature preserves. In Last Stand Protected Areas and the Defense of Tropical Biodiversity (eds R. Kramer, C.P. van Schaik \& J. Johnson), pp. 64-89. Oxford University Press, New York, USA.

Walpole, M.J. \& Goodwin, H.J. (2000) Local economic impacts of dragon tourism in Indonesia. Annals of Tourism Research, 27, 559-576.

Walpole, M.J. \& Leader-Williams, N. (2001) Masai Mara tourism reveals partnership benefits. Nature, 413, 771.

Wells, M. (1992) Biodiversity conservation, affluence and poverty - mismatched costs and benefits and efforts to remedy them. Ambio, 21, 237-243.

Wells, M. (1997) Economic Perspectives on Nature Tourism, Conservation and Development. World Bank, Washington, DC, USA.

Wells, M., Guggenheim, S., Khan, A., Wardojo, W. \& Jepson, P. (1999) Investing in Biodiversity: A Review of Indonesia's Integrated Conservation and Development Projects. World Bank, Washington, DC, USA.

White, A.T., Vogt, H.P. \& Arin, T. (2000) Philippine coral reefs under threat: the economic losses caused by reef destruction. Marine Pollution Bulletin, 40, 598-605.

World Bank. (2002) World Development Indicators 2002. World Bank, Washington, DC, USA.

World Bank (2003) BioCarbon Fund.

http:/ / www.biocarbonfund.org [accessed 7 April 2003].

Yaron, G. (2001) Forest plantations or small-scale agriculture? An economic analysis of alternative land use options in the Mount Cameroon area. Journal of Environmental Planning and Management, 44, 85-108.

\section{Biographical sketches}

Andrew Balmford is a senior lecturer in the Department of Zoology, University of Cambridge, where he helps run a 15-strong conservation biology group, as well as an annual international student conference on conservation science. His research is largely based in the tropics and focuses on how to identify priorities for conservation action, how much effective conservation costs in comparison to the benefits it delivers, and how best to reconcile conservation with other forms of land use.

Tony Whitten is a Senior Biodiversity Specialist at the World Bank in Washington DC where he attempts to speak for the trees and to achieve conservation of forests, wildlife, karst biota and freshwater biodiversity by whatever means. He has written many books on the ecology and natural history of Indonesia, and now works throughout the East Asia region, from Mongolia to New Guinea, where he manages conservation and research/capacity projects, a regional project on religions and forests, and is brought into normal Bank projects in the context of environmental assessments for Bank-financed projects. 